\title{
以中华优秀传统美德推动高校立德树人根本 任务实现的路径研究
}

\section{Research On the Path to Realize the Fundamental Task of Promoting Strengthen Moral Education and Cultivate People in Universities By Virtues of Chinese Tradition Virtues}

魏博文 李函书

Bowen Wei Hanshu Li

沈阳工业大学 中国·辽宁 沈阳 110870

Shenyang University of Technology, Liaoning, Sengyang,110870, China

摘 要: 中华优秀传统美德与高校立德树人的任务之间联系紧密, 高校传承中华优秀传统美德在提升学生道德素质、推动 高校人才培养、坚定社会文化自信等方面具有重要意义，以中华优秀传统美德来推动高校立德树人任务的实现是一条可行 的路径。

\begin{abstract}
There is a close connection between the tradition Chinese virtues and the task of establishing moral education in colleges and universities. Inheriting the traditional Chinese virtues is great significance in improving students' moral quality, promoting personnel training and strengthening cultural confidence, so it is a feasible way to promote the realization of the task of establishing morality in colleges and universities by using the traditional Chinese virtues.
\end{abstract}

关键词：立德树人; 中华优秀传统美德；德育；人才培养

Keywords: strengthen moral education and cultivate people; excellent Chinese traditional virtues; moral education; talent cultivation

DOI: $10.36012 /$ sde.v3i1.2854

立德树人是新时期教育的根本任务，如何实现立德树 人的根本任务值得深思。中华优秀传统美德在内涵上与目标 上都与立德树人任务联系紧密，传承中华优秀传统美德意义 重大。以中华优秀传统美德作为推动, 从课程思政与思政课 堂发展、学生活动与校园文化建设、领导机制与考评制度完 善等方面实现立德树人任务，是现实可行的。

\section{1 中华优秀传统美德与高校立德树人任务 之间的联系}

中华优秀传统美德与高校立德树人任务之间具有很强 的联系性，尤其体现在内涵上的联系与目标上的联系。

\section{1 中华优秀传统美德与高校立德树人任务的内} 涵联系

中国是世界四大文明古国之一，在几千年不断向前的 发展中形成了中华民族优秀的传统美德。中华优秀传统美 德源远流长、博大精深，通过历朝历代的不断完善基本上 形成了以“仁”、“义”、“礼”、“智”、“信”为核心的价值 理念。“仁”是指在与人相互交往时亲爱、同情、关心的 态度;“义”是指在交往时秉持的正直、善良、道义的气节; “礼”是指礼貌、礼节、礼仪等规矩; “智” 指能够分辨是非、 分辨善恶、知已识人的能力; “信”指诚实、可靠、敢当 的品格。

【作者简介】魏博文 (1993 ) 男, 辽宁抚顺人, 硕士研究生学历, 助教, 从事思想政治教育研究。 
“立德树人” 是教育永恒的使命与责任, 它既是一个发 展性概念, 又是一个整体性概念。即使不同时期有不同的育 人目标, 但是始终贯穿着 “立德树人” 的教育宗旨。中华优 秀传统美德与高校立德树人在内涵上紧密相连, 他们都是催 人向善, 讲求美德的传承。

\section{2 弘扬中华优秀传统美德与实现高校立德树人 任务的目标联系}

中华优秀传统美德由中国五千年历史孕育而出, 在新 时期中华优秀传统美德与时俱进、向前发展。弘扬中华优秀 传统美德的目标便是要充分发挥其对于人的影响。首先, 是 对中华传统文化与民族精神的继承与发展。一个民族、一个 国家要立足于不败之地, 必须要有奋发向上的精神, 这个精 神由这个民族每一个人的精神组成, 又反过来影响着这个民 族的每一个人。其次, 是对当代青年学子思想道德素质的提 升。青年强则国强, 青年是国家的未来。中华优秀传统美德 对当代青年学子人格的塑造、价值观的形成具有极强影响。

立德树人, 就是坚持德育为先, 坚持以人为本。高校 立德树人任务的目标, 就是不断提高学生的思想水平、政治 觉悟、道德品质、文化素养, 为党、为国家、为民族培养一 代又一代德智体美劳全面发展的社会主义合格建设者和可 靠接班人。立德树人, 立的是社会主义道德, 树的是有理想、 有道德、有文化、有纪律的人。弘扬中华优秀传统美德与实 现高校立德树人任务在目标上具有紧密的联系性与相当的 一致性。他们都以人的培养、以国家和民族的整体进步作为 目标, 强调优良的品德与素质。

\section{2 高校传承中华优秀传统美德的重要意义}

高校中年轻一代的学子对社会的发展具有带动和促进 的功能。高校传承中华优秀传统美德, 对提高学生道德素养, 推动高校人才培养、坚定社会文化自信、具有重要意义。

\section{1 提升学生道德素养}

中华优秀传统美德根植于中华优秀传统文化的沃土, 对 大学生的思想道德教育提供了源源不断的营养。在时代高速 发展的今天, 人们的道德素养, 特别是作为祖国未来的大学 生们的道德水平的提升能否赶得上社会发展的速度, 值得深 思。高校对大学生进行中华优秀传统美德的教育, 对大学生 们道德素养的提升, 具有重要意义。
传承中华优秀传统美德, 可以使大学生建立正确的政 治意识, 树立正确的国家观念。道德素养的提升, 首要便是 政治素养的提升, 大学生通过传统美德, 形成热爱伟大祖国、 关心国家大事的政治意识和较强的民族情感 ; 传承中华优秀 传统美德, 可以使大学生树立正确的三观, 培养高尚的情操。 三观影响人们的思维方式和行为习惯, 通过传承传统美德, 大学生能够在对待事件、处理问题时不至于过度偏激, 在日 常生活学习中形成良好的爱好和习惯, 树立远大理想抱负, 形成谦虚谨慎性格品格, 树立正直诚信人性品性。

\section{2 推动高校人才培养}

我国教育的根本任务, 就是培养社会主义合格建设者 和可靠接班人, 培养一代又一代拥护中国共产党领导和我国 社会主义制度、立志为中国特色社会主义奋斗终身的有用人 才。这充分体现出 “德” 育教育在人才培养的重要性。高校 进行人才培养时, “德育” 必不可少, 中华传统美德传承千年, 历久弥新, 在高校人才培养中能够起到强有力的推动作用。 高校可以利用多种形式, 使学生在校期间更多的接受到传统 美德的教育, 养成乐观、开朗、谦虚、谨慎的性格, 形成勤学、 勤思、勤奋、勤勉的习惯, 在校园内打造出良好的学习氛围 和生活环境, 从而形成良性循环, 促进学生多方面的进步和 提高, 从而推动高校的人才培养。

\section{3 坚定社会文化自信}

中华民族能够傲立于世界民族之林, 没有对自己文化 的坚定自信是不行的。在全球化不断加深的浪潮之中, 要想 顺应时代发展的趋势, 同时又不被外来糟粕文化所侵蚀, 保 持自身的文化独立性，没有全社会的文化自信是不行的。坚 定全社会的文化自信，必须到中华民族传统文化的沃土中汲 取养分, 中华优秀传统美德便是强劲的 “营养剂”。高校传 承与时俱进的中华传统美德, 可以激发人们的爱国热情, 培 育集体观念, 促进人们思维方式和行为举止的转变, 通过年 轻一代的高校学子来带动、促进全社会文化自信的培育, 促 进传统文化与时代发展的有机融合, 不断发掘出中华文化中 新的动能, 发展出中华文化向前迈进的新的途径, 赋予时代 新的内涵, 体现中华优秀传统文化新的价值。传承中华优秀 传统美德，可以进一步动员全社会自觉弘扬中华优秀传统文 化, 自觉践行社会主义核心价值观, 自觉提高个人道德素质, 促进全社会大环境的提升, 使人们在大环境潜移默化的影响 
下坚定文化自信。

\section{3 以中华优秀传统美德推动高校立德树人 任务实现的路径}

高校立德树人任务的实现需要中华优秀传统美德的推 动, 可以从大力推动课程思政与思政课堂的发展、充分利用 学生活动与校园文化建设、建立健全领导机制与考评制度完 善几个方面探寻实现路径。

\section{1 大力推动课程思政与思政课堂发展}

课堂是高校育人的主阵地, 高校要实现立德树人的目 标任务课堂教育必不可少。在高校对学生进行思想政治教育 中, 课程思政与思政课堂是两把利器。思政课堂是目前高校 进行思想政治教育最主要的途径, 但是思政课堂依然面临着 教育资源地域分布不均衡、优秀专业教师较少、课程设置不 合理、受重视程度不够等问题。课程思政在高校中面临着覆 盖率不高、任课教师教学质量低、师生态度不积极、教育目 的与理念不够深入人心等更为棘手的问题。所以, 实现立德 树人任务目标，就必须大力推动课程思政与思政课堂的发 展, 通过更加体系化的课程设计、有实效的宣传手段来提升 任课教师的教学质量、提高全体教师对课程思政与思政课堂 的重视程度, 解决突出问题。同时, 将中华优秀传统美德教 育代入到课堂教学活动当中, 以更为通俗、更加接地气的方 式将正确的世界观、人生观、价值观传递给正在快速获取知 识的大学生, 以推动立德树人目标任务的实现。

\section{2 充分利用学生活动与校园文化建设}

高校在进行教学改革实践以及培育学生成长成才的过 程中, 越来越认识到除了 “第一课堂”之外, “第二课堂” 的重要性。第二课堂, 即是有利于学生全面发展与综合素质 提升的有组织性、纪律性的校内外课外活动。因为与传统的 课堂教学相比, 学生活动更多的是学生自主参与其中、自愿
参加的, 所以在积极性上、在热情上、在自主性上都要相对 更高一些。在大学这个学生自我意识、价值意识形成确定的 关键时期, 学生活动已然成为大学生提高思想品德修养的重 要载体。校园文化建设是一种环境教育, 对学生的成长成才 起着潜移默化的影响，它不仅是创造一种氛围，更是体现了 一种精神。良好的校园文化建设对学生健全人格的养成、道 德情操的陶冶意义重大。将中华优秀传统美德融入到学生课 外活动与校园文化建设中, 利用好学生参与活动的热情, 最 大化发挥出学生活动与校园文化建设的教育与影响功能, 是 高校实现立德树人目标任务的一条可行路径。

\section{3 建立健全领导机制与考评制度完善}

高校立德树人任务的实现绝不是单靠说说而已，而是 需要真抓实干, 特别是需要高校的领导对实现立德树人目标 任务的重视。高校需要形成实现立德树人目标任务的领导机 制, 构建领导体系, 明确实施主体，深人学习领会立德树人 的目标任务, 科学研究、科学判断、科学规划、科学实施、 科学监督, 以健全的领导机制应对目标任务实现过程中可能 出现的问题以及对学校整体任务实现路径进行有效把握。将 立德树人目标任务的实现纳入到有关主体的考评中去，形成 完善的关于立德树人目标任务实现考评制度，促进有关上级 领导与下级部门对其认识的深化, 提高重视程度, 及时发现 问题，督促任务实施，明确责任主体，形成有效联动，从制 度与机制上保证立德树人目标任务的实现。

\section{参考文献}

[1] 唐丹. 将中华优秀传统文化与高校立德树人任务融合的实践探 索 [J]. 智库时代, 2018(43): 197-198.

[2] 陈琦. 高校提高弘扬中华优秀传统美德教育的方法与路径研究 [J]. 西南科技大学学报: 哲学社会科学版, 2018(1): 75-78.

[3] 张天华, 廖雪. 高校立德树人根本任务的实现路径研究 [J]. 渤 海大学学报, 2020(4): 135-138. 